\title{
Article \\ Polyacrylonitrile Derived Robust and Flexible Poly(ionic liquid)s Nanofiber Membrane as Catalyst Supporter
}

\author{
Yue Gao ${ }^{1,2}$, Qing-Bo Meng ${ }^{1, *}$, Bao-Xin Wang ${ }^{1}$, Yu Zhang ${ }^{1}$, Hui Mao ${ }^{1}$, Da-Wei Fang ${ }^{1}$ and Xi-Ming Song ${ }^{1, *}$ \\ 1 Liaoning Key Laboratory for Green Synthesis and Preparative Chemistry of Advanced Materials, \\ College of Chemistry, Liaoning University, Shenyang 110036, China; yueyuezcs@163.com (Y.G.); \\ 7duan@163.com (B.-X.W.); zhangyu@lnu.edu.cn (Y.Z.); huimao@lnu.edu.cn (H.M.); \\ davidfine@163.com (D.-W.F.) \\ 2 International School, Shenyang Polytechnic College, Shenyang 110045, China \\ * Correspondence: mengqb@lnu.edu.cn (Q.-B.M.); songlab@lnu.edu.cn (X.-M.S.)
}

check for updates

Citation: Gao, Y.; Meng, Q.-B.; Wang, B.-X.; Zhang, Y.; Mao, H.; Fang, D.-W.; Song, X.-M.

Polyacrylonitrile Derived Robust and Flexible Poly(ionic liquid)s Nanofiber Membrane as Catalyst Supporter. Catalysts 2022, 12, 266. https:// doi.org/10.3390/catal12030266

Academic Editors: Mehrab Mehrvar and Marta Gmurek

Received: 5 February 2022

Accepted: 24 February 2022

Published: 26 February 2022

Publisher's Note: MDPI stays neutral with regard to jurisdictional claims in published maps and institutional affiliations.

Copyright: (C) 2022 by the authors. Licensee MDPI, Basel, Switzerland. This article is an open access article distributed under the terms and conditions of the Creative Commons Attribution (CC BY) license (https:// creativecommons.org/licenses/by/ $4.0 /$ )

\begin{abstract}
Poly(ionic liquid)s nanofiber (PIL NF) membrane was derived from polyacrylonitrile by converting its cyano groups to imidazoline moieties via cyclization with ethylenediamine, followed by quaternization with 1-bromobutane. The novel PIL NF is further decorated with photocatalyst phosphotungstic acid PW12 via anion exchanging to give PW-PIL. The degradation rate of the novel supported photocatalyst towards methyl orange irradiated under visible light was found to be $98 \%$. In addition, the nanofiber membrane morphology is beneficial for easy recycling, and $98 \%$ of original degradation rate was maintained after 5 cycles of photocatalysis degradation. This robust, efficient, and recyclable material offers a new approach for serving as catalyst supporter. The photocatalyst PW-PIL is reported for the first time. The inexpensive functional membrane is used to exploit the sun as a cheap and clean source of light.
\end{abstract}

Keywords: poly(ionic liquid)s; polyacrylonitrile; nanofiber membrane; visible light photocatalyst

\section{Introduction}

Polyacrylonitrile nanofiber (PAN NF) membrane has quite a few advantages including low density, good flexibility, low cost, and is applied in various areas such as the textile industry, construction materials and precursor of carbon fiber [1-4]. Besides, application of PAN could also be extended to other fields including adsorption of metal-ions, catalysis or catalyst supporter, by converting chemically active cyano groups in PAN into other kinds of functional groups such as amino [5], carboxyl [6], and imidazoline [7]. These achievements inspire us to further develop novel functional materials from PAN NF membrane, by utilization of their abundant cyano groups [8].

Poly(ionic liquid)s (PILs) have gained great interest in material research due to their favorable properties of both ionic liquid and conventional polyelectrolyte, especially for serving as a supporter of functional materials via simple anion exchanging. PILs are traditionally prepared via classic free radical polymerization of ionic liquid monomers with vinyl groups [9]. This method is widely employed and easy to handle, but its applicability is often limited by the lower degree of polymerization [10]. Another way to obtain PILs is by modifying the nitrogen-containing side groups (e.g., imidazole, pyridine) existing in synthesized polymer. Since PAN could be converted to poly(2-vinylimidazoline) via cyclization reaction with ethylenediamine, we can expect that the PAN-based PILs can be derived via ionization of the imidazoline groups while maintaining the degree of polymerization and nanofiber membrane morphology of PAN.

Recently, handling wastewater containing organic dyes has been an emerging topic for researchers [11]. At present, several methods such as membrane separation, adsorption and biochemical degradation technology have been developed [12], but their applications are limited by their relatively low removal rate of pollutants, production of secondary pollution 
or harmful intermediates and so forth [13-16]. Recently, the photocatalytic degradation of organic dyes in wastewater, especially by irradiation with visible light, has attracted much attention from scientists [17-19], because photocatalysis is an effective way to consume renewable energy, which is more environmentally friendly than other catalytic systems. Polyoxometalates (POMs) are a class of stable transition metal oxides with excellent photochemical properties similar to semiconductors $[20,21]$, but the separation and recycling of water-soluble POMs is still a challenge. Loading POMs on supporters is considered to be an effective method to solve the problem [22-24], and developing inexpensive, accessible and stable supporters with high immobilization capacity are required.

Table 1 shows the development of photocatalytic membrane materials in recent years. We compare and analyze the research status of photocatalysts from the following aspects: the raw materials, preparation method, degradation materials, preparation cost, reusability, and visible light response. The conclusion being that the preparation of a visible light responsive, low cost, easy recovery, good flexibility, insoluble in water, simple preparation method of polymer catalyst is an effective way to degrade dye wastewater.

Table 1. The development of photocatalytic membrane materials.

\begin{tabular}{|c|c|c|c|c|c|c|}
\hline $\begin{array}{l}\text { Photocatalytic } \\
\text { Membrane }\end{array}$ & Membrane Preparation Method & $\begin{array}{l}\text { Degradation } \\
\text { Material }\end{array}$ & Cost & Recyclability & $\begin{array}{l}\text { Visible } \\
\text { Light }\end{array}$ & Reference \\
\hline PW-PIL membrane & $\begin{array}{l}\text { Free-standing } \\
\text { photocatalytic membrane }\end{array}$ & $\begin{array}{l}\text { MO wastewater } \\
\text { degradation }\end{array}$ & Economic PAN & $\begin{array}{l}\text { Insoluble } \\
\text { Easy } \\
\text { Flexibility }\end{array}$ & Response & \\
\hline $\mathrm{Al}_{2} \mathrm{O}_{3} / \mathrm{TiO}_{2}$ & Coated on the photocatalytic membrane & $\begin{array}{l}\text { Carbamazepine } \\
\text { degradation }\end{array}$ & $\begin{array}{c}\text { Expensive } \\
\mathrm{TiO}_{2}, \mathrm{Al}_{2} \mathrm{O}_{3}\end{array}$ & $\begin{array}{l}\text { Soluble } \\
\text { Difficult } \\
\text { Rigidity }\end{array}$ & No response & {$[25]$} \\
\hline Ceramic/ $\mathrm{TiO}_{2}$ & Coated on the photocatalytic membrane & $\begin{array}{c}\text { Acid Red } 4 \\
\text { degradation }\end{array}$ & $\begin{array}{l}\text { Expensive } \\
\mathrm{TiO}_{2}\end{array}$ & $\begin{array}{l}\text { Soluble } \\
\text { Difficult } \\
\text { Rigidity }\end{array}$ & No response & [26] \\
\hline $\mathrm{PVDF} / \mathrm{TiO}_{2}$ & Blended into the membrane matrix & $\begin{array}{l}\text { Wastewater } \\
\text { degradation }\end{array}$ & $\begin{array}{l}\text { Expensive } \\
\mathrm{TiO}_{2}\end{array}$ & $\begin{array}{l}\text { Insoluble } \\
\text { Difficult } \\
\text { Flexibility }\end{array}$ & No response & [27] \\
\hline $\mathrm{PU} / \mathrm{ZnO}$ & Dip-coating on the membrane & $\begin{array}{c}\text { MB degradation, } \\
\text { antimicrobial } \\
\text { activity }\end{array}$ & $\begin{array}{l}\text { Expensive } \\
\mathrm{ZnO}\end{array}$ & $\begin{array}{l}\text { Insoluble } \\
\text { Difficult } \\
\text { Flexibility }\end{array}$ & No response & [28] \\
\hline $\mathrm{CNT} / \mathrm{ZnO}-\mathrm{TiO}_{2}$ & Dip-coating on the membrane & MB degradation & $\begin{array}{l}\text { Expensive } \\
\mathrm{TiO}_{2}, \mathrm{ZnO}\end{array}$ & $\begin{array}{l}\text { Soluble } \\
\text { Difficult } \\
\text { Rigidity }\end{array}$ & No response & [29] \\
\hline $\mathrm{PVDF} / \mathrm{ZnO}-\mathrm{TiO}_{2}$ & $\begin{array}{l}\text { Chemical vapor deposition on the } \\
\text { membrane }\end{array}$ & MB degradation & $\begin{array}{l}\text { Expensive } \\
\mathrm{TiO}_{2}, \mathrm{ZnO}\end{array}$ & $\begin{array}{l}\text { Soluble } \\
\text { Difficult } \\
\text { Flexibility }\end{array}$ & No response & [30] \\
\hline $\mathrm{PSF} / \mathrm{Cu}_{2} \mathrm{O}$ & Hydrothermal synthesis on the membrane & Removal of IBP & $\begin{array}{l}\text { Expensive } \\
\mathrm{Cu}_{2} \mathrm{O}\end{array}$ & $\begin{array}{l}\text { Insoluble } \\
\text { Easy } \\
\text { Flexibility }\end{array}$ & Response & [31] \\
\hline $\mathrm{GO} / \mathrm{Fe}_{2} \mathrm{O}_{3}-\mathrm{TiO}_{2}$ & Dip-coating on the membrane & $\begin{array}{l}\text { Humic Acid } \\
\text { Removal from } \\
\text { Water }\end{array}$ & $\begin{array}{c}\text { Expensive } \\
\mathrm{TiO}_{2}, \mathrm{Fe}_{2} \mathrm{O}_{3}\end{array}$ & $\begin{array}{l}\text { Soluble } \\
\text { Difficult } \\
\text { Rigidity }\end{array}$ & No response & [32] \\
\hline $\mathrm{PVDF} / \mathrm{ZnIn}_{2} \mathrm{~S}_{4}$ & Dip-coating on the membrane & $\begin{array}{l}\text { Removal of } \\
\text { tetracycline }\end{array}$ & $\begin{array}{l}\text { Expensive } \\
\mathrm{ZnIn}_{2} \mathrm{~S}_{4}\end{array}$ & $\begin{array}{l}\text { Insoluble } \\
\text { Easy } \\
\text { Flexibility }\end{array}$ & Response & [33] \\
\hline $\mathrm{RGO} / \mathrm{Bi}_{2} \mathrm{WO}_{6}$ & Dip-coating on the membrane & Removal of CIP & $\begin{array}{l}\text { Expensive } \\
\mathrm{Bi}_{2} \mathrm{WO}_{6}\end{array}$ & $\begin{array}{l}\text { Soluble } \\
\text { Difficult } \\
\text { Rigidity }\end{array}$ & Response & [34] \\
\hline $\mathrm{RGO} / \mathrm{PDA} / \mathrm{Bi}_{12} \mathrm{O}_{17} \mathrm{Cl}_{2}$ & Dip-coating on the membrane & $\begin{array}{l}\text { Degradation MB } \\
\text { and oil/water } \\
\text { separation }\end{array}$ & $\begin{array}{l}\text { Expensive } \\
\mathrm{Bi}_{12} \mathrm{O}_{17} \mathrm{Cl}_{2}\end{array}$ & $\begin{array}{l}\text { Soluble } \\
\text { Easy } \\
\text { Rigidity }\end{array}$ & Response & [35] \\
\hline Steel $/ \mathrm{CeO}_{2}$ & Dip-coating on the membrane & $\begin{array}{l}\text { Removal of MB } \\
\text { pollutants }\end{array}$ & $\begin{array}{l}\text { Expensive } \\
\mathrm{CeO}_{2}\end{array}$ & $\begin{array}{l}\text { Soluble } \\
\text { Difficult } \\
\text { Rigidity }\end{array}$ & No response & [36] \\
\hline Ceramic/ $/ \mathrm{TiO}_{2}$ & Dip-coating on the membrane & Removal of HA & $\begin{array}{l}\text { Expensive } \\
\mathrm{TiO}_{2}\end{array}$ & $\begin{array}{l}\text { Soluble } \\
\text { Difficult } \\
\text { Rigidity }\end{array}$ & No response & [37] \\
\hline $\mathrm{PVDF} / \mathrm{TiO}_{2}$ & Electrospinning and hydrothermal reaction & $\begin{array}{l}\mathrm{CO}_{2} \\
\text { photoreduction }\end{array}$ & $\begin{array}{l}\text { Expensive } \\
\mathrm{TiO}_{2}\end{array}$ & $\begin{array}{l}\text { Soluble } \\
\text { Easy } \\
\text { Flexibility }\end{array}$ & No response & [38] \\
\hline $\mathrm{PES} / \mathrm{TiO}_{2}$ & Physical deposition & $\begin{array}{c}\text { Acid Red1 } \\
\text { degradation }\end{array}$ & $\begin{array}{l}\text { Expensive } \\
\mathrm{TiO}_{2}\end{array}$ & $\begin{array}{l}\text { Soluble } \\
\text { Difficult } \\
\text { Rigidity }\end{array}$ & No response & [39] \\
\hline
\end{tabular}

In the present work, low-cost and flexible PAN NF membranes are modified to PILs and furthermore decorated with photocatalytic active POM phosphotungstic acid (PW12). The photocatalytic properties of the as-obtained PW-PIL composite membrane were in- 
vestigated for degradation of methyl orange (MO) under visible light, and this kind of composite photocatalytic material with high molecular weight and nanofiber membrane morphology exhibited good catalytic ability and recyclability.

\section{Results and Discussion}

\subsection{Characterization of PW-PIL NF Membrane}

The PAN, PVIm, Br-PIL, PW-PIL NF membranes and PW12 were characterized by FT-IR, and the spectra were collected in Figure $1 \mathrm{a}$. The peak at $1451 \mathrm{~cm}^{-1}$ in the spectrum of PAN represents the in-plane vibrations of C-H. The peaks at 2246 and $1074 \mathrm{~cm}^{-1}$ are appointed as the stretching and bending vibrations of $\mathrm{C} \equiv \mathrm{N}$ [40-42]. In the spectrum of PVIm, the characteristic peak at $2246 \mathrm{~cm}^{-1}$ associated with $\mathrm{C} \equiv \mathrm{N}$ disappears, while the new peaks at 1673 and $1389 \mathrm{~cm}^{-1}$ are assigned to the stretching vibration of $\mathrm{C}=\mathrm{N}$ and $\mathrm{C}-\mathrm{N}$ in imidazoline ring, suggesting the successful conversion of the $\mathrm{C} \equiv \mathrm{N}$ group to imidazoline unit via cyclization with ethylenediamine [43,44]. Furthermore, in the PW12 spectrum, the peaks at 1074, 998, 892 and $813 \mathrm{~cm}^{-1}$ are assigned as the vibration of $\mathrm{P}-\mathrm{O}, \mathrm{W}-\mathrm{O}, \mathrm{W}-$ $\mathrm{O}-\mathrm{W}_{\text {corner }}$ and $\mathrm{W}-\mathrm{O}-\mathrm{W}_{\text {edge, }}$, respectively. In the (PW-PIL) IR spectrum, the peaks at 1074 and $998 \mathrm{~cm}^{-1}$ related to the vibration of the $\mathrm{P}-\mathrm{O}$ group and the $\mathrm{W}-\mathrm{O}$ resonance appeared, while the peaks at 1673 and $1074 \mathrm{~cm}^{-1}$ related to imidazoline can be seen [45], implying successful production of desired PW-PIL composite.

(a)

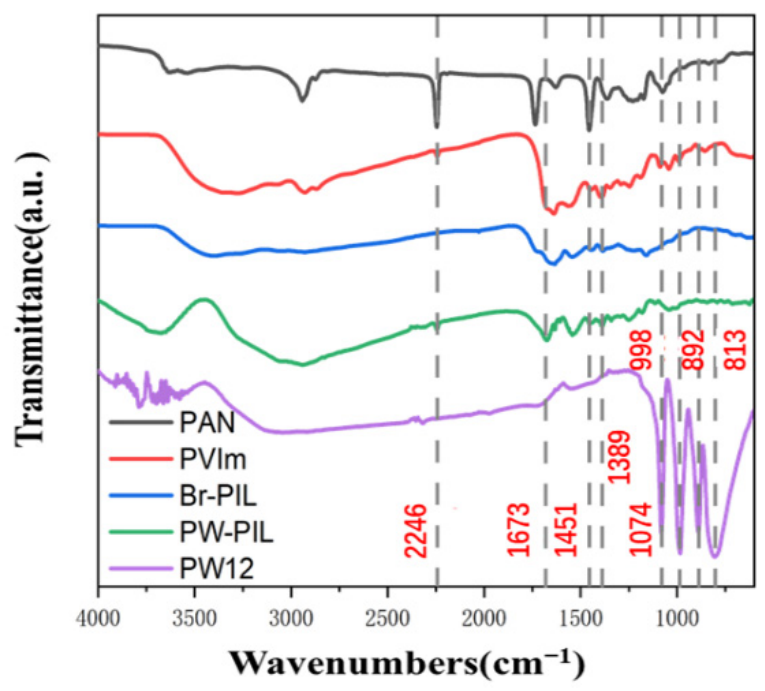

(b)
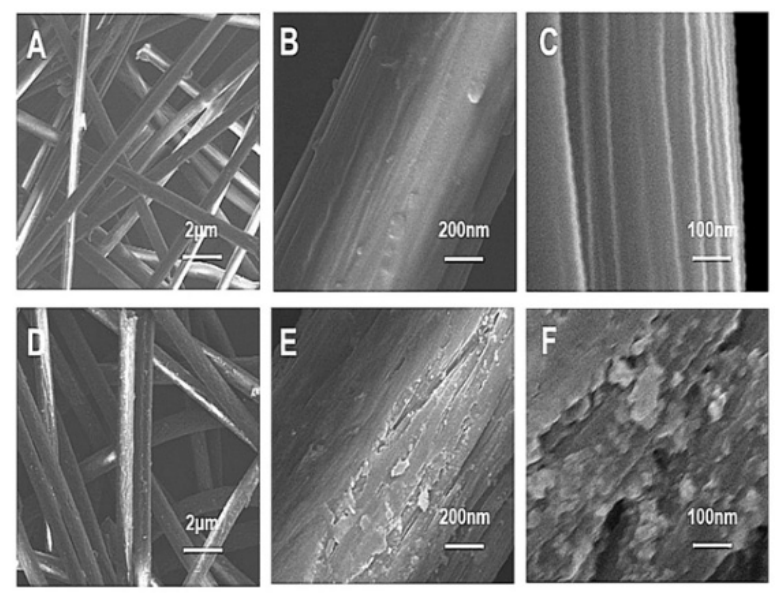

Figure 1. (a) FT-IR spectra of PAN, PVIm, Br-PIL, PW-PIL and PW12. (b) SEM images of PAN NF membrane (A-C) and PW-PIL NF membrane (D-F) with $2 \mu \mathrm{m}, 200 \mathrm{~nm}$ and $100 \mathrm{~nm}$ magnification.

Figure $1 b$ shows the SEM images of PAN and PW-PIL NF membranes. Compared to the PAN, the surface of PW-PIL is rougher, which is mostly attributed to uniformly distributed POM on the PW-PIL. In addition, honeycomb like cavity can be observed on the surface of PW-PIL NF, which may increase surface area of the membrane as well as adsorption capacity [46] and could be anticipated as an ideal polymer-supporter.

XPS analysis is conducted to investigate the chemical composition of the surface and the elemental chemical states of the as-prepared samples. The elements of $C, O$ and $N$ can be detected on the surface of PAN. The $\mathrm{C}$ and $\mathrm{N}$ elements result from PAN molecules, while the elements of $\mathrm{P}$ and $\mathrm{W}$ are assigned to PW12 (Figure 2a). The W content is $5.14 \%$, suggesting that the anion exchange process was successful. High-resolution XPS was employed to monitor the $\mathrm{N}$ element Binding Energy (Figure $2 \mathrm{~b}$ ). The $\mathrm{N}_{1 \mathrm{~S}}$ peak at $400.7 \mathrm{eV}\left(\mathrm{N}_{1}\right)$ and $402.3 \mathrm{eV}\left(\mathrm{N}_{2}\right)$ belong to the imidazolinium. In Figure $2 \mathrm{c}$, the XPS spectrum indicates that the intensity ratio of $\mathrm{C}_{15}$. $\mathrm{C}-\mathrm{C}$ has the highest peak, and the remaining two peaks were from $\mathrm{C}-\mathrm{N}$ and $\mathrm{C}=\mathrm{N}$, respectively. 
(a)

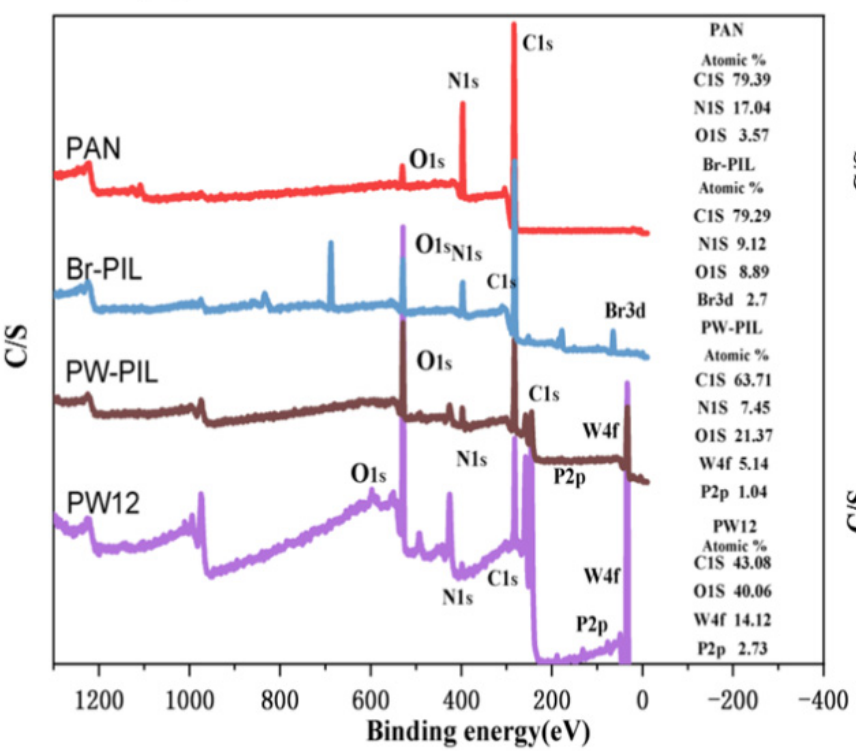

(b)
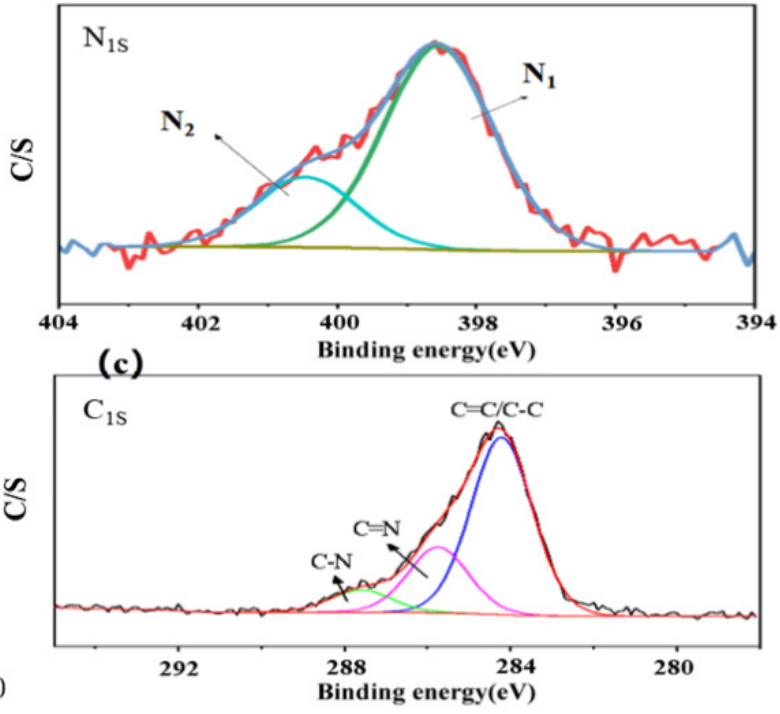

Figure 2. (a) XPS survey spectra of PAN, Br-PIL, PW-PIL and PW12; (b) high-resolution XPS spectra of $\mathrm{N}_{1 \mathrm{~s}}$ in PW-PIL; (c) high-resolution XPS spectra of $\mathrm{C}_{1 \mathrm{~s}}$ in PW-PIL.

In order to inspect the light absorption features of the raw and modified materials, UV-visible diffuse reflectance spectra (DRS) of the PAN, PW12, PVIm, Br-PIL and PW-PIL NF membranes were measured, and the results are shown in Figure 3a. As expected, no significant absorption could be observed for PAN in both the UV and visible region. Similarly, pure PW12 exhibited little absorption in the visible area $(>400 \mathrm{~nm})$. Nevertheless, PW-PIL exhibits significant absorption in the UV and visible area, indicating that visiblelight absorption of PW12 photocatalyst could be effectively improved by the charge mobility of the PIL [47]. The bandgap energy between energy bands of PW-PIL is $3.09 \mathrm{eV}$ (KubelkaMunk theory) according to the UV-vis diffuse reflectance spectra.
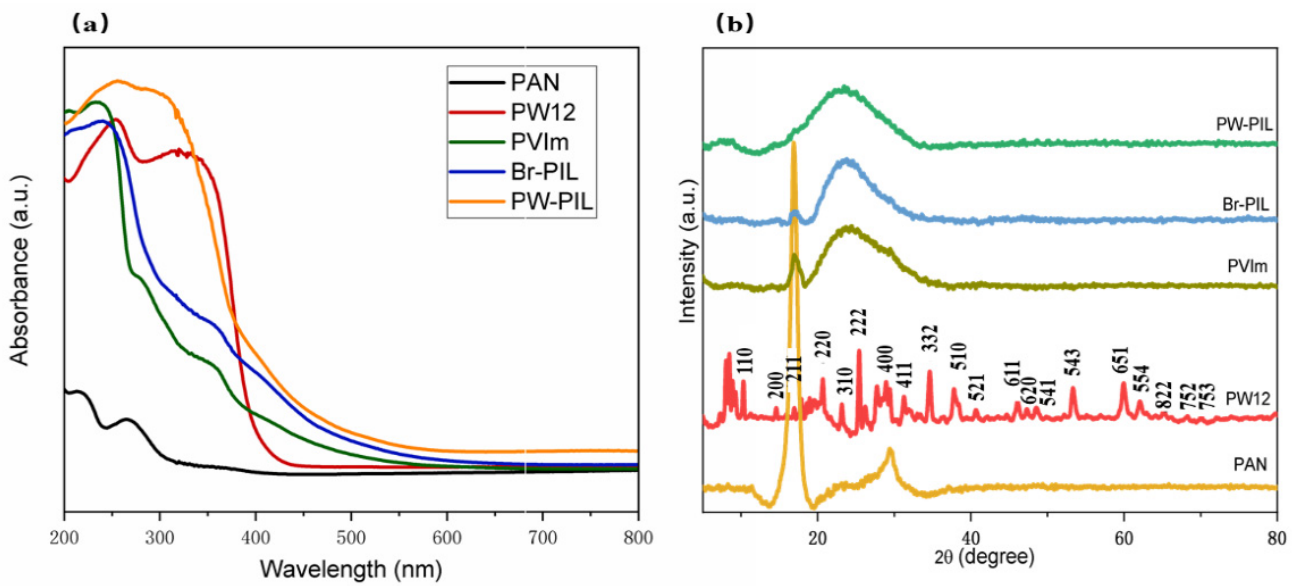

Figure 3. (a) The UV-vis diffuse reflectance spectra of PAN, Br-PIL and PW-PIL, PW12. (b) XRD patterns of PAN, PW12, PVIm, Br-PIL and PW-PIL.

X-ray diffraction measurements on the sample PAN, PW12, PVIm, Br-PIL and PWPIL were performed for confirming their crystal structure, and the relevant results were collected in the Figure 3b. For PAN NF membrane, a diffraction peak could be observed at the range of 16 to 17 of $2 \theta$, which should be attributed to the hexagonal (100) crystal plane [48]. Another weaker crystal diffraction peak (110) is present at a $2 \theta$ value of about 28 to 29. In the Figure 3 a of PVIm, the decrease in the $2 \theta$ value of 17 and the change of others in the (100) diffraction peak can be attributed to the production of an imidazoline group. 
In the sample of PW12, the $2 \theta$ values are at $10,20,23,25,28$, and 31 corresponding to the $(110,200,220,310,222,400)$ crystal form of PW12, respectively, as reported in the reference [49]. This assignment is advocated by correlation with the XRD pattern of PW12, in which all peaks are observed on the JCPDS number 50-0657 card. In the case of Br-PIL, the $2 \theta$ value of 17 is equal to that in the PVIm, and the $2 \theta$ value of 29 is significantly weakened [50]. The comparison of the Br-PIL and PVIm patterns demonstrate that the ionization does not significantly the crystal form of PVIm. In the diffraction pattern of PWPIL, no impurity peaks can be observed, and comparing with PAN, the peaks associated with $2 \theta$ values of 17,29 disappear, while the two novel peaks appear at the $2 \theta$ values of 8,23 correspond to the PW12 (200) and (001) crystal form, further suggesting successful synthesis of PW-PIL.

\subsection{Photodegradation of Methyl Orange under Visible Light}

The visible light-based photocatalytic degradation reaction of MO was carried out in water. Methyl orange is an azo dye whose chromophores are mainly azo fragments. The main degradation method of azo dyes is chemical oxidation, in the presence of oxidants such as POM or ozone, azo fragments can be oxidized. Thus, degrading MO is used to verify the experiment. The results are shown in Figure 4a [51]. In comparison, control experiments were also performed by conducting the photocatalytic degradation in the absence of PW-PIL or simply blending PAN with PW12 under the same experimental condition. The concentration change of $\mathrm{MO}$ during catalysis process was monitored by measuring UV-visible spectra of samples separated from the solution at a given interval. The results demonstrate the degradation rate under dark conditions is only $1 \%$, but $98 \%$ of MO is rapidly degraded in the presence of PW-PIL after the equal period under visible light irradiation, and the colour change of $\mathrm{MO}$ aqueous solution in the course of the photocatalytic degradation process is shown in Figure 4c. These results indicate that PW-PIL is an efficient photocatalyst for the degradation of MO [52,53]. In addition, from Figure 4a. B we can find that simply blending the PAN and the PW12 can only obtain c.a. $20 \%$ photocatalytic degradation under the same conditions.
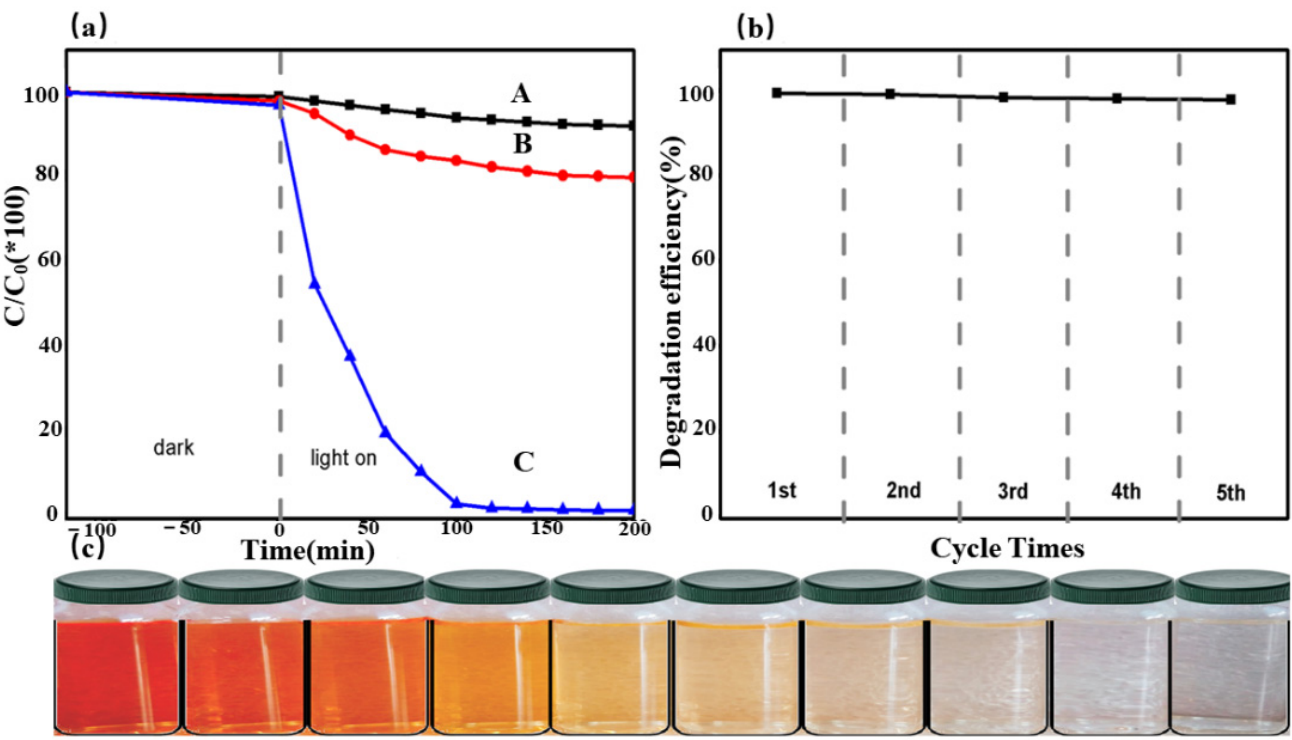

Figure 4. (a) Absorption of Methyl orange in the dark and consequent photocatalytic degradation without photocatalyst (A), with the blending of PAN and PW12 (B), in the presence of PW-PIL (C) under visible light irradiation; (b) Recyclability of the supported photocatalyst PW-PIL. Concentration of the photocatalyst is $1 \mathrm{mg} \mathrm{mL}^{-1}$ (20 mg in $20 \mathrm{~mL}$ aqueous solution); concentration of $\mathrm{MO}$ is $50 \mathrm{ppm}$; on average, five samples are taken in $100 \mathrm{~min}$; (c) Appearance of methyl orange aqueous solution during the photocatalytic degradation process at an interval of $10 \mathrm{~min}$. 
For investigating the recyclability of the supported catalyst, PW-PIL NF membrane was separated from the photocatalytic reaction system and subsequently washed with deionized water and ethanol three times, respectively, followed by drying in a vacuum oven at $60{ }^{\circ} \mathrm{C}$ for $8 \mathrm{~h}$ to perform the new cycle of photocatalysis experiments under the identical condition. The results shown in Figure $4 \mathrm{~b}$ indicate that after five cycles, $98 \%$ of the initial degradation rate of MO could be maintained, suggesting that PW-PIL NF membrane is an effective photocatalyst and convenient for recyclization since the membrane morphology can avoid the additional centrifugation process which is usually necessary for recovery of the powder like catalyst supports, and the strong Coulombic force between the negative charged PW12 and the positive charged imidazolinium group allows higher immobilization stability of the photocatalyst PW12.

A potential mechanism from aspects of molecule energy and structure is given in Figures 5 and 6. The bandgap energy between energy bands of PW-PIL is $3.09 \mathrm{eV}$ (KubelkaMunk theory) according to the UV-vis diffuse reflectance spectra, indicating that PW-PIL can effectively absorb visible light [54]. As the imidazolinium groups with the positive charge can seize the negatively charged PW12 via coulombic interaction, a built-in field could be formed between PW12 and PIL chain, which would enhance the transfer of photo generated electrons. It is known that POM can be considered as a low dimensional semiconductor structure [55]. Under visible light irradiation, electrons of PW12 excite from valence band (VB) energy level to conduction band (CB) energy level, and the photogenerated electrons entering $\mathrm{CB}$ energy level react with $\mathrm{O}_{2}$ on surface to form $\mathrm{O}^{2-}$, while the photogenerated holes of $\mathrm{VB}$ level react with $\mathrm{OH}^{-}$to form $\cdot \mathrm{OH}$, which further degrades MO. $\mathrm{H}_{2} \mathrm{O}_{2}$ acts as an initiator to form $\cdot \mathrm{OH}$ with $\mathrm{O}^{2-}[56-58]$.

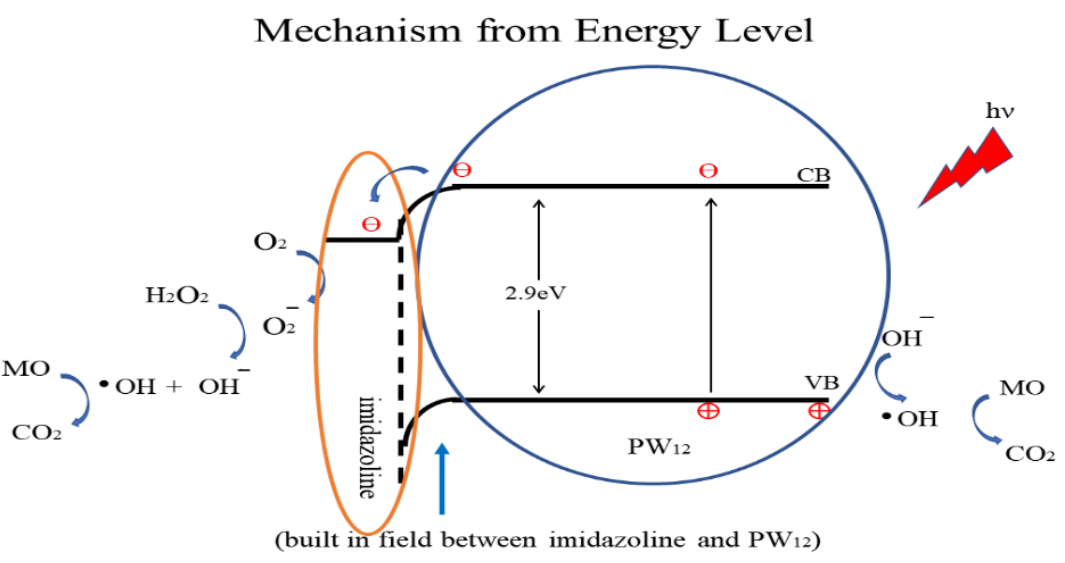

Figure 5. Energy-band diagrams for PW-PIL structure, and the separation of charge carriers under irradiation.

Mechanism from Structure

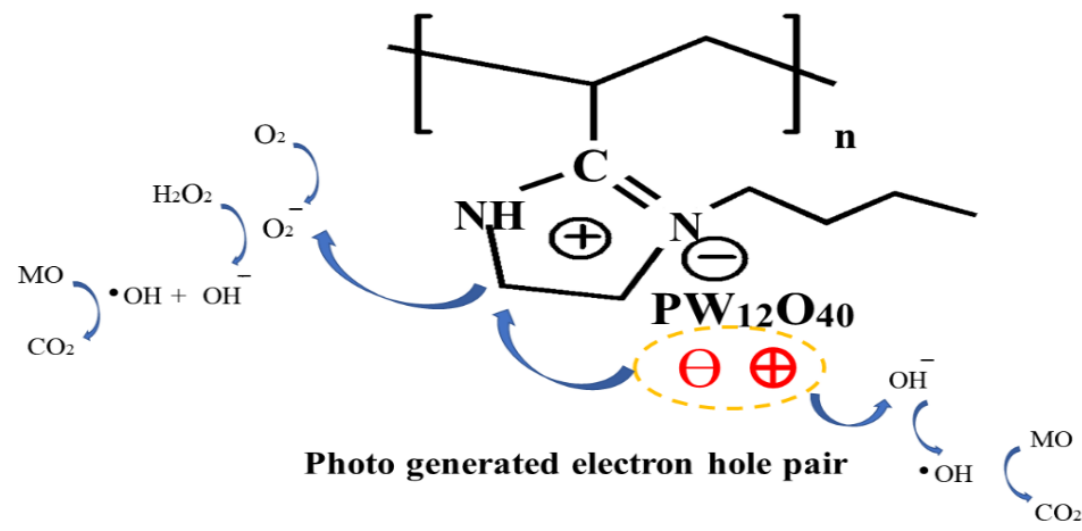

Figure 6. Mechanism diagrams for PW-PIL structure. 


\section{Experimental}

\subsection{Materials and Methods}

Polyacrylonitrile nanofiber (PAN NF, Mw = 150,000) electrospinning membrane was purchased from Fushun Petrochemical Company. N, N-dimethylformamide (DMF), hydrogen peroxide, ethylene diamine, toluene, ethanol, phosphotungstic acid, 1-bromobutane, methyl orange, ethylene glycol and acetone were purchased from Aladdin Reagent co. as analytical pure agents and used without further purification. All the reagents used in the article are analytical pure.

\subsection{Synthesis of Imidazolin Group-Containing Polymers}

PAN NFs membrane (200 mg) was cut and immersed in a mixture of ethylene glycol $(2 \mathrm{~mL})$, ethylenediamine $(2 \mathrm{~mL})$ and DMF $(20 \mathrm{~mL})$ in $\mathrm{H}_{2} \mathrm{O}(20 \mathrm{~mL})$ and the mixture was heated to $80{ }^{\circ} \mathrm{C}$ and maintained for $4 \mathrm{~h}$ under $\mathrm{N}_{2}$ atmosphere. After the mixture was naturally cooled down the modified membrane was washed with deionized water and acetone for three times, respectively, and then dried in vacuum oven at $60{ }^{\circ} \mathrm{C}$ for $8 \mathrm{~h}$, to obtain an imidazoline group-containing poly(2-vinylimidazolinium) membrane, which was designated as PVIm [7].

\subsection{Synthesis of Br-Based Poly(ionic liquid)s NF Membrane}

The PVIm NFs membrane $(100 \mathrm{mg})$ and 1-bromobutane $(1 \mathrm{~mL})$ were added in DMF $(40 \mathrm{~mL})$ and then the temperature was elevated to $80{ }^{\circ} \mathrm{C}$ to conduct the quaternization reaction for $24 \mathrm{~h}$. After cooling down, the obtained light-yellow membrane was washed with water and ethanol for three times, respectively, and then dried in vacuum oven at $60{ }^{\circ} \mathrm{C}$ for $8 \mathrm{~h}$, to obtain a PIL membrane containing Br- anion, poly(1-butyl-2-vinylimidazolinium) bromide, which was designated as Br-PIL.

\subsection{Synthesis of $\mathrm{PW}_{12} \mathrm{O}_{40}{ }^{3-}$ Based Poly(ionic liquid)s NF Membrane}

Phosphotungstic acid (100 mg) and Br-PIL (20 mg) were added in water (40 mL) and stirred at $60{ }^{\circ} \mathrm{C}$ for $4 \mathrm{~h}$ to perform ion exchange reaction. The obtained greyishgreen membrane was washed with deionized water for three times, and then dried in a vacuum oven at $60{ }^{\circ} \mathrm{C}$ for $8 \mathrm{~h}$ to obtain a PIL membrane with $\mathrm{PW}_{12} \mathrm{O}_{40}{ }^{3-}$ as counter anion, poly(1-butyl-2-vinylimidazolinium) phosphotungstate, which was designated as PW-PIL (Scheme 1).

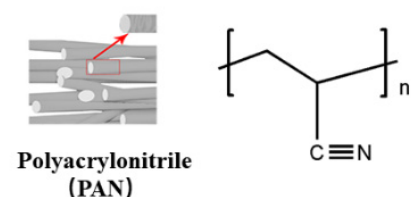

(PAN)
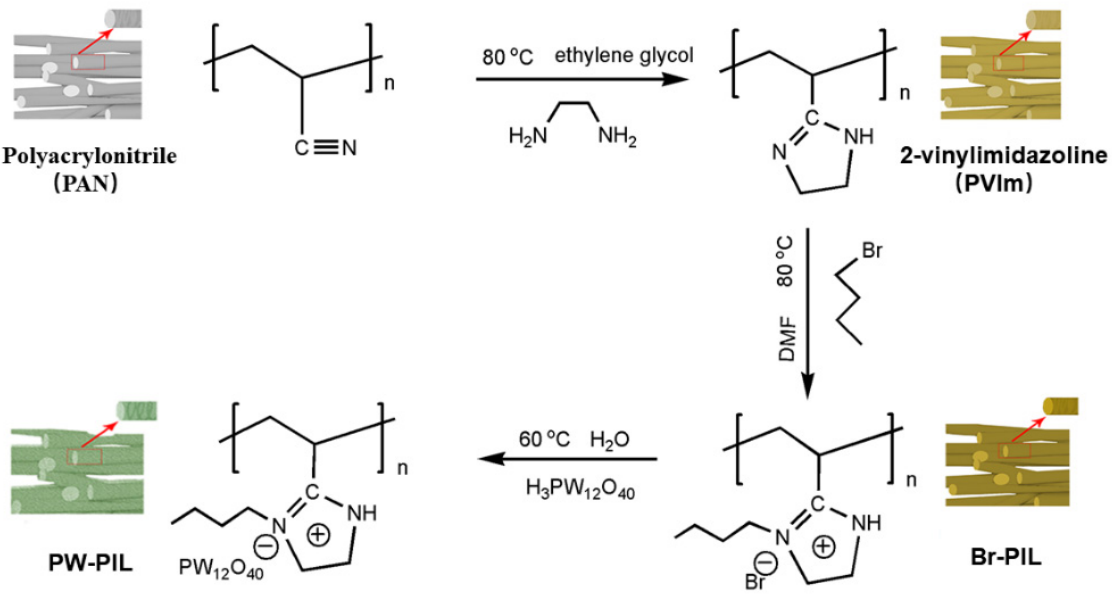

Scheme 1. Synthetic route of PVIm, Br-PIL and PW-PIL.

\subsection{Preparation of PW-PIL NF Membranes}

The synthetic route of PW-PIL NF membrane is shown in Scheme 1. Briefly, the PAN NF membrane was fabricated using an electrospinning method, and their cyano groups were converted to imidazoline moieties via cyclization with ethylenediamine. 
The obtained poly(2-vinylimidazoline) (denominated as PVIm) was subsequently ionized by 1-bromobutane to give Br-based poly(ionic liquid) (Br-PIL), which was further anion exchanged with phosphotungstate acid PW12 to obtain the PW-PIL NF membrane.

\subsection{Photocatalytic Degradation of Methyl Orange (MO) and Recyclization}

The photocatalytic performance of the sample was determined using a 500-watt xenon lamp (CHFXQ500W, Beijing Integrity Technology Co., Ltd. (Beijing, China)) as the light source to control the wavelength of light with a $400 \mathrm{~nm}$ filter plate. The radiation intensity was $100 \mathrm{~mW} / \mathrm{cm}^{2}$. The visible light-based photocatalytic degradation reaction of $\mathrm{MO}$ was carried out in water. Briefly, PW-PIL $(20 \mathrm{mg})$ and hydrogen peroxide $(10 \mu \mathrm{L})$ were added to a $50 \mathrm{ppm}$ aqueous solution $(20 \mathrm{~mL})$ of $\mathrm{MO}$, and the mixture was initially stirred (with magneton for magnetic stirring) in dark for $120 \mathrm{~min}$. Afterwards photocatalytic degradation of MO was conducted under irradiation of a $500 \mathrm{~W}$ xenon lamp (using a $400 \mathrm{~nm}$ optical filter to filter off ultraviolet light) for $2 \mathrm{~h}$ at room temperature. For comparison, control experiments were also performed by conducting the photocatalytic degradation without photocatalyst or in the presence of blending of PAN with PW12 under the same experimental condition. The concentration change of $\mathrm{MO}$ during catalysis process was monitored by measuring UV- visible spectra of samples separated from the solution at an interval of $20 \mathrm{~min}$. For investigating the recyclability of the supported catalyst, PW-PIL NF membrane was separated from the photocatalytic reaction system and subsequently washed with deionized water and ethanol for three times, respectively, followed by drying in a vacuum oven at $60^{\circ} \mathrm{C}$ for $8 \mathrm{~h}$ to perform the new cycle of photocatalysis experiments under the identical condition.

\subsection{Characterization}

The morphology of the sample was observed by scanning electron microscopy (SEM) (Hitachi S-4800, operating at $15 \mathrm{kV}$ ). The UV-visible spectra of liquid samples were measured with an ultraviolet spectrophotometer (TU 1901). UV-visible diffuse reflectance spectra (DRS) of solid samples were performed using a Shimadzu-2550 UV system with a reference to $\mathrm{BaSO}_{4}$ in the range of 200-800 nm. Fourier transferred Infrared (FT-IR) spectra were recorded using a Perkin Elmer 1600 infrared spectrophotometer. X-ray diffraction spectra of the samples in the range of $5-90^{\circ}$ were characterized using a Rigaku $\mathrm{D} / \mathrm{max}-2500$ diffractometer operating at $40 \mathrm{kV}$ and $150 \mathrm{~mA}(\lambda=0.15406 \mathrm{~nm})$. The degree of anion exchange was determined using X-ray photoelectron spectroscopy (XPS) (ESCALAB MK II). Photoluminescence of a $150 \mathrm{~W}$ ozone-free Xe source was recorded on a fluorescence spectrophotometer (FS5-TCSPC Edinburgh Instruments, Livingston, UK).

\section{Conclusions}

In conclusion, a robust, flexible, and recyclable PIL NF membrane decorated with photocatalyst POM is prepared by modification of low-cost raw material PAN NF membrane through cyclization reaction, ionization and anion exchanging process, and then employed for photo degradation of $\mathrm{MO}$ under irradiation of visible light. The degradation rate was found to be around $98 \%$ and can be well maintained after 5 cycles. From the perspective of economic benefit, the market price of PILs is c.a. \$150 thousand dollars per $\mathrm{kg}$, while the price of PAN is only one million of PILs. In addition, the photocatalyst is mostly in powder form, meaning that the additional centrifugation process is required for recycling, while the membrane photocatalyst is much easier to recycle. The photocatalyst PW-PIL is reported for the first time. The inexpensive functional PIL NF membrane could be in principle produced on a large scale and give rise to more economical photodegradation approaches. A sustainable process can be obtained when a photocatalytic membrane utilises the sun as a cheap and clean source of light. On this aspect, the development of new photocatalysts with high activity under visible light and their application in the various research fields is a mandatory task. 
Author Contributions: Material preparation, catalytic experiments and writing-original draft, Y.G.; writing-review \& editing, Q.-B.M.; data analysis, Q.-B.M., Y.Z., H.M. and D.-W.F.; theoretical investigation, B.-X.W.; original idea and supervision, X.-M.S. All authors have read and agreed to the published version of the manuscript.

Funding: This work is supported by the National Natural Science Foundation of China (No.51773085 and 51803084).

Data Availability Statement: The data that support the findings of this study are available from the corresponding author upon reasonable request.

Conflicts of Interest: The authors declare no conflict of interest.

\section{References}

1. Bode-Aluko, C.A.; Pereao, O.; Ndayambaje, G.; Petrik, L. Adsorption of toxic metals on modified polyacrylonitrile nanofibers: A review. Water Air Soil Pollut. 2017, 228, 1-11. [CrossRef]

2. Geller, B.E. Polyacrylonitrile fibres. Prospects for development of production. A review. Fiber Chem. 1997, 29, 341-345. [CrossRef]

3. Geller, B.E. Status and prospects for development of polyacrylonitrile fiber production. A review. Fiber Chem. 2002, 34, 151-161. [CrossRef]

4. Li, L.; Wang, X.-F.; Zhong, J.-J.; Qian, X.; Song, S.-L.; Zhang, Y.-G.; Li, D.-H. Nitrogen-Enriched Porous Polyacrylonitrile-Based Carbon Fibers for $\mathrm{CO}_{2}$ Capture. Ind. Eng. Chem. Res. 2018, 57, 11608-11616. [CrossRef]

5. Morcali, M.H.; Zeytuncu, B. Investigation of adsorption parameters for platinum and palladium onto a modified polyacrylonitrilebased sorbent. Int. J. Miner. Process. 2015, 137, 52-58. [CrossRef]

6. Li, Y.; Wang, H.; Lu, J.; Chu, A.; Zhang, L.; Ding, Z.; Xu, S.; Gu, Z.; Shi, G. Preparation of immobilized lipase by modified polyacrylonitrile hollow membrane using nitrile-click chemistry. Bioresour. Technol. 2018, 274, 9-17. [CrossRef]

7. Lin, K.; Song, M.; Cai, D.; Hao, X.; Wu, Y. Polymer (fiber)-supported palladium catalyst containing imidazolinyl rings and its application to the Heck reaction. Tetrahedron Lett. 2003, 44, 3955-3957. [CrossRef]

8. Almasian, A.; Jalali, M.; Fard, G.C.; Maleknia, L. Surfactant grafted PDA-PAN nanofiber: Optimization of synthesis, characterization and oil absorption property. Chem. Eng. J. 2017, 326, 1232-1241. [CrossRef]

9. Miao, L.; Liu, G.; Wang, J. Ag-nanoparticle-bearing poly(vinylidene fluoride) nanofiber mats as Janus filters for catalysis and separation. ACS Appl. Mater. Interfaces 2019, 11, 7397-7404. [CrossRef]

10. Lu, J.; Yan, F.; Texter, J. Advanced applications of ionic liquids in polymer science. Prog. Polym. Sci. 2009, 34, 431-448. [CrossRef]

11. Baldez, E.E.; Robaina, N.F.; Cassella, R.J. Employment of polyurethane foam for the adsorption of Methylene Blue in aqueous medium. J. Hazard. Mater. 2008, 159, 580-586. [CrossRef]

12. Hu, F.; Fang, C.; Wang, Z.; Liu, C.; Zhu, B.; Zhu, L. Poly(N-vinyl imidazole) gel composite porous membranes for rapid separation of dyes through permeating adsorption. Sep. Purif. Technol. 2017, 188, 1-10. [CrossRef]

13. Esther, F.; Tibor, C.; Gyula, O. Removal of synthetic dyes from wastewaters: A review. Environ. Int. 2004, 30, 953-971.

14. Yu, S.; Wang, X.; Ai, Y.; Liang, Y.; Ji, Y.; Li, J.; Hayat, T.; Alsaedi, A.; Wang, X. Spectroscopic and theoretical studies on the counterion effect of $\mathrm{Cu}(\mathrm{ii})$ ion and graphene oxide interaction with titanium dioxide. Environ. Sci. Nano 2016, 3, 1361-1368. [CrossRef]

15. Yuan, Y.J.; Ye, Z.J.; Lu, H.W.; Hu, B.; Li, Y.H.; Chen, D.Q.; Zhong, J.S.; Yu, Z.T.; Zou, Z.G. Constructing anatase TiO 2 nanosheets with exposed (001) facets/layered $\mathrm{MoS}_{2}$ two-dimensional nanojunctions for enhanced solar hydrogen generation. ACS Catal. 2016, 6, 532-541. [CrossRef]

16. Molinari, R.; Lavorato, C.; Argurio, P.; Szyma 'nski, K.; Darowna, D.; Mozia, S. Overview of Photocatalytic Membrane Reactors in Organic Synthesis, Energy Storage and Environmental Applications. Catalysts 2019, 9, 239. [CrossRef]

17. Han, X.; Han, Z.; Li, J.; Zhao, J.; Zhao, X. Coordinative integration of copper (II) and iron (II) phthalocyanine into amidoximated PAN fiber for enhanced photocatalytic activity under visible light irradiation. J. Colloid Interface Sci. 2018, 533, 333-343. [CrossRef]

18. Sun, W.; Li, X.; Shao, C.; Li, X.; Zhao, L.; Lu, N.; Liu, Y. Controllable preparation of three-dimensional porous $\mathrm{WO}_{3}$ with enhanced visible light photocatalytic activity via a freeze-drying method. J. Mater. Sci. Mater. Electron. 2018, 29, 9605-9612. [CrossRef]

19. Li, X.; Yin, R.; Liu, Y.; Luo, Q.; An, J.; Wang, D.; Liu, S.; Dai, B. Enhanced visible light photocatalytic activity of zno nanoparticles modified by cyclized polyacrynitrile. Environ. Prog. Sustain. Energy 2018, 38, 336-344. [CrossRef]

20. Keita, B.; Nadjo, L. Polyoxometalate-based homogeneous catalysis of electrode reactions: Recent achievements. J. Mol. Catal. A Chem. 2007, 262, 190-215. [CrossRef]

21. Zhang, G.; Keita, B.; Biboum, R.N.; Miserque, F.; Berthet, P.; Dolbecq, A.; Mialane, P.; Catala, L.; Nadjo, L. Synthesis of various crystalline gold nanostructures in water: The polyoxometalate $\beta-\left[\mathrm{H}_{4} \mathrm{PMo}_{12} \mathrm{O}_{40}\right]^{3}-$ as the reducing and stabilizing agent. J. Mater. Chem. 2009, 19, 8639-8644. [CrossRef]

22. Ji, X.; Zhang, Q.; Qu, X.; Wang, Q.; Song, X.-M.; Liang, F.; Yang, Z. Poly(ionic liquid) Janus nanosheets towards dye degradation. RSC Adv. 2015, 5, 21877-21880. [CrossRef] 
23. Tang, X.; Hou, Y.; Meng, Q.B.; Zhang, G.; Liang, F.; Song, X.M. Heteropoly acids-functionalized Janus particles as catalytic emulsifier for heterogeneous acylation in flow ionic liquid-in-oil Pickering emulsion. Colloids Surf. A. Physicochem. Eng. Asp. 2019, 570, 191-198. [CrossRef]

24. Li, Q.; Guo, J.; Chen, Y.; Kim, H. Preparation and characterization of polyacrylonitrile doped PVDF/heteropoly acid composite membranes. High Perform. Polym. 2012, 24, 282-288. [CrossRef]

25. Horovitz, I.; Avisar, D.; Baker, M.A.; Grilli, R.; Lozzi, L.; Di Camillo, D.; Mamane, H. Carbamazepine degradation using a N-doped $\mathrm{TiO}_{2}$ coated photocatalytic membrane reactor: Influence of physical parameters. J. Hazard. Mater. 2016, 310, 98-107. [CrossRef]

26. Wang, W.-Y.; Irawan, A.; Ku, Y. Photocatalytic degradation of Acid Red 4 using a titanium dioxide membrane supported on a porous ceramic tube. Water Res. 2008, 42, 4725-4732. [CrossRef]

27. Dzinun, H.; Othman MH, D.; Ismail, A.F.; Puteh, M.H.; Rahman, M.A.; Jaafar, J. Stability study of PVDF/TiO 2 dual layer hollow fibre membranes under long-term UV irradiation exposure. J. Water Process Eng. 2017, 15, 78-82. [CrossRef]

28. Kim, J.H.; Joshi, M.K.; Lee, J.; Park, C.H.; Kim, C.S. Polydopamine-assisted immobilization of hierarchical zinc oxide nanostructures on electrospun nanofibrous membrane for photocatalysis and antimicrobial activity. J. Colloid Interface Sci. 2018, 513, 566-574. [CrossRef]

29. Feng, J.; Xiong, S.; Wang, Y. Atomic layer deposition of hybrid metal oxides on carbon nanotube membranes for photodegradation of dyes. Compos. Commun. 2018, 12, 39-46. [CrossRef]

30. De Filpo, G.; Pantuso, E.; Armentano, K.; Formoso, P.; Di Profio, G.; Poerio, T.; Fontananova, E.; Meringolo, C.; Mashin, A.I.; Nicoletta, F.P. Chemical Vapor Deposition of Photocatalyst Nanoparticles on PVDF Membranes for Advanced Oxidation Processes. Membranes 2018, 8, 35. [CrossRef]

31. Singh, R.; Yadav, V.; Purkait, M.K. $\mathrm{Cu}_{2} \mathrm{O}$ photocatalyst modified antifouling polysulfone mixed matrix membrane for ultrafiltration of protein and visible light driven photocatalytic pharmaceutical removal. Sep. Purif. Technol. 2018, 212, 191-204. [CrossRef]

32. Rao, G.; Zhang, Q.; Zhao, H.; Chen, J.; Li, Y. Novel titanium dioxide/iron (III) oxide/graphene oxide photocatalytic membrane for enhanced humic acid removal from water. Chem. Eng. J. 2016, 302, 633-640. [CrossRef]

33. Gao, B.; Chen, W.; Liu, J.; An, J.; Wang, L.; Zhu, Y.; Sillanpää, M. Continuous removal of tetracycline in a photocatalytic membrane reactor (PMR) with ZnIn2S4 as adsorption and photocatalytic coating layer on PVDF membrane. J. Photochem. Photobiol. A: Chem. 2018, 364, 732-739. [CrossRef]

34. Li, Y.; Zhu, L. Evaluation of the antifouling and photocatalytic properties of novel poly(vinylidene fluoride) membranes with a reduced graphene oxide- $\mathrm{Bi}_{2} \mathrm{WO}_{6}$ active layer. J. Appl. Polym. Sci. 2017, 134. [CrossRef]

35. Yu, Z.; Min, X.; Li, F.; Yin, D.; Peng, Y.; Zeng, G. A mussel-inspired method to fabricate a novel reduced graphene oxide $/ \mathrm{Bi}_{12} \mathrm{O}_{17} \mathrm{Cl}_{2}$ composites membrane for catalytic degradation and oil/water separation. Polym. Adv. Technol. 2018, 30, 101-109. [CrossRef]

36. Baig, U.; Matin, A.; Gondal, M.; Zubair, S. Facile fabrication of superhydrophobic, superoleophilic photocatalytic membrane for efficient oil-water separation and removal of hazardous organic pollutants. J. Clean. Prod. 2018, 208, 904-915. [CrossRef]

37. Alias, S.S.; Harun, Z.; Latif, I.S.A. Characterization and performance of porous photocatalytic ceramic membranes coated with $\mathrm{TiO}_{2}$ via different dip-coating routes. J. Mater. Sci. 2018, 53, 11534-11552. [CrossRef]

38. Dong, P.; Huang, Z.; Nie, X.; Cheng, X.; Jin, Z.; Zhang, X. Plasma enhanced decoration of nc-TiO 2 on electrospun PVDF fibers for photocatalytic application. Mater. Res. Bull. 2019, 111, 102-112. [CrossRef]

39. Kovács, I.; Beszédes, S.; Kertész, S.; Veréb, G.; Hodúr, C.; Papp, I.Z.; Kukovecz, A.; László, Z. Investigation of Titanium-Dioxide Coatings on Membrane Filtration Properties. Studia Univ. Babes-Bolyai Chem. 2017, 62, 249-259. [CrossRef]

40. Sampathkumar, R.; Sabesan, R.; Krishnan, S. Dipole moment studies of the structure of 2,6-diaryl-4-piperidones. J. Mol. Liq. 2006, 130, 2-6. [CrossRef]

41. Zhang, Z.; Liao, Z.; Zhang, G. Degradation performance of a Keggin type Zn-Mo-Zr catalyst for acidic green B with ultrasonic waves. RSC Adv. 2015, 5, 63104-63110. [CrossRef]

42. Wang, H.; Huang, X.; Li, W.; Gao, J.; Xue, H.; Li, R.K.; Mai, Y.-W. TiO 2 nanoparticle decorated carbon nanofibers for removal of organic dyes. Colloids Surf. A Physicochem. Eng. Asp. 2018, 549, 205-211. [CrossRef]

43. Cheng, H.; Huang, B.; Yang, K.; Wang, Z.; Qin, X.; Zhang, X.; Dai, Y. Facile Template-Free Synthesis of Bi ${ }_{2} \mathrm{O}_{2} \mathrm{CO}_{3} \mathrm{Hierarchical}$ Microflowers and Their Associated Photocatalytic Activity. ChemPhysChem 2010, 11, 2167-2173. [CrossRef] [PubMed]

44. Yang, J.; Chu, S.; Guo, Y.; Luo, L.; Kong, F.; Wang, Y.; Zou, Z. Hyperbranched polymeric N-oxide: A novel kind of metal-free photocatalyst. Chem. Commun. 2012, 48, 3533-3535. [CrossRef]

45. Huang, Y.; Yuan, Z.; Zhao, D.; Wang, F.; Zhang, K.; Li, Y.; Wen, Y.; Wang, C. Polymyxin B immobilized nanofiber sponge for endotoxin adsorption. Eur. Polym. J. 2018, 110, 69-75. [CrossRef]

46. Luo, Q.; Yang, X.; Zhao, X.; Wang, D.; Yin, R.; Li, X.; An, J. Facile preparation of well-dispersed, Z.nO/cyclized polyacrylonitrile nanocomposites with highly enhanced visible-light photocatalytic activity. Appl. Catal. B Environ. 2017, 204, 304-315. [CrossRef]

47. Xue, G.; Dai, Q.; Jiang, S. Chemical reactions of imidazole with metallic silver studied by the use of SERS and XPS techniques. J. Am. Chem. Soc. 1988, 110, 2393-2395. [CrossRef]

48. Zhou, M.; Yu, J. Preparation and enhanced daylight-induced photocatalytic activity of C,N,S-tridoped titanium dioxide powders. J. Hazard. Mater. 2008, 152, 1229-1236. [CrossRef]

49. Zhou, Q.; Li, L.; Zhang, X.; Yang, H.; Cheng, Y.; Che, H.; Wang, L.; Cao, Y. Construction of heterojunction and homojunction to improve the photocatalytic performance of $\mathrm{ZnO}$ quantum dots sensitization three-dimensional ordered hollow sphere $\mathrm{ZrO}_{2}-\mathrm{TiO}_{2}$ arrays. Int. J. Hydrogen Energy 2020, 45, 31812-31824. [CrossRef] 
50. Ndlwana, L.; Raleie, N.; Dimpe, M.; Ogutu, H.; Motsa, M.M.; Mamba, B.B. Sustainable Hydrothermal and Solvothermal, Synthetic Approaches for Advanced Carbon Materials in Multidimensional Applications: A Review. Preprints 2021. [CrossRef]

51. Taghavi, M.; Ehrampoush, M.H.; Ghaneian, M.T.; Tabatabaee, M.; Fakhri, Y. Application of a Keggin-type heteropoly acid on supporting nanoparticles in photocatalytic degradation of organic pollutants in aqueous solutions. J. Clean. Prod. 2018, 197, 1447-1453. [CrossRef]

52. Zhong, J.B. Photocatalytic decolorization of methyl orange solution with phosphotungstic acid. Iran. J. Chem. Chem. Eng. 2013, 32, 57-65.

53. Maeda, K.; Teramura, K.; Saito, N.; Inoue, Y.; Kobayashi, H.; Domen, K. Overall water splitting using (oxy)nitride photocatalysts. Pure Appl. Chem. 2006, 78, 2267-2276. [CrossRef]

54. Rauf, M.; Ashraf, S. Fundamental principles and application of heterogeneous photocatalytic degradation of dyes in solution. Chem. Eng. J. 2009, 151, 10-18. [CrossRef]

55. Chen, G.; Sun, M.; Wei, Q.; Zhang, Y.; Zhu, B.; Du, B. Ag $\mathrm{PO}_{4}$ /graphene-oxide composite with remarkably enhanced visible-lightdriven photocatalytic activity toward dyes in water. J. Hazard. Mater. 2013, 244, 86-93. [CrossRef] [PubMed]

56. Ge, H.; Tian, H.; Zhou, Y.; Wu, S.; Liu, D.; Fu, X.; Song, X.-M.; Shi, X.; Wang, X.; Li, N. Influence of Surface States on the Evaluation of the Flat Band Potential of $\mathrm{TiO}_{2}$. ACS Appl. Mater. Interfaces 2014, 6, 2401-2406. [CrossRef] [PubMed]

57. Song, X.; Zhou, X.; Yuan, C.; Zhang, Y.; Tong, Q.; Li, Y.; Cui, L.; Liu, D.; Zhang, W. One-dimensional $\mathrm{Fe}_{2} \mathrm{O}_{3} / \mathrm{TiO}_{2}$ photoelectrode and investigation of its photoelectric properties in photoelectrochemical cell. Appl. Surf. Sci. 2017, 397, 112-118. [CrossRef]

58. Mendes-Felipe, C.; Veloso-Fernández, A.; Vilas-Vilela, J.L.; Ruiz-Rubio, L. Hybrid Organic-Inorganic Membranes for Photocatalytic Water Remediation. Catalysts 2022, 12, 180. [CrossRef] 